\title{
The Impact of Dizziness on the Quality of Life of 235 Individuals who Completed Vestibular Testing in Brazil
}

\author{
Najlla Lopes de Oliveira Burle ${ }^{1}$ Ana Célia Pereira de Abreu ${ }^{2} \quad$ Juliana Nunes Santos ${ }^{1}$ Patricia Cotta Mancini ${ }^{1}$ \\ ${ }^{1}$ Speech Therapy Department, Universidade Federal de Minas Gerais, \\ Belo Horizonte, Minas Gerais, Brazil \\ 2 Speech Therapy Department, Hospital Evangélico, Belo Horizonte, \\ Minas Gerais, Brazil \\ Address for correspondence Patricia Cotta Mancini, PhD, Speech \\ Therapy Department, Universidade Federal de Minas Gerais, Avenida \\ Alfredo Balena, 190 sala 251, Faculdade de Medicina Santa Efigênia, \\ Belo Horizonte, Minas Gerais 30130-100, Brazil \\ (e-mail: patmancini@gmail.com; pmancini@medicina.ufmg.br).
}

Int Arch Otorhinolaryngol 2016;20:54-60.

\begin{abstract}
Keywords

- postural balance

- dizziness

- quality of life

- electronystagmography

- caloric tests
\end{abstract}

\section{Introduction}

The equilibrium of the body is the ability of human beings to remain in the upright position, perform acceleration, and rotational movements of the body without oscillating or falling. ${ }^{1}$ To maintain body equilibrium, proper interaction of vestibular, and proprioceptive visual systems is neces-

received

February 21, 2015

accepted

May 1, 2015

published online

July 16, 2015 sary. ${ }^{2}$ A disorder in the relation between these systems commonly manifests itself in an individual through dizziness, characterized by a sense of motion of the body or the surroundings. ${ }^{3}$

Individuals with chronic dizziness may experience symptoms such as insecurity and fear, which may consequently cause isolation from society, thus impacting their quality of
Copyright $(2016$ by Thieme Publicações License terms Ltda, Rio de Janeiro, Brazil

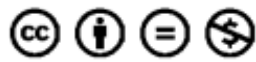


life. ${ }^{4-6}$ A study reports that by the age of 65 , dizziness is the second most prevalent symptom in the world, and above this age, it is the most prevalent. ${ }^{7}$ Santana et al. claim that dizziness is present in $5-10 \%$ of the world population and is present in $65 \%$ of individuals older than 65 years. ${ }^{8}$

Vestibular testing (VT) aims to analyze the functioning of the labyrinth and its relationship with other systems. ${ }^{9}$ The survey is used to confirm the data obtained during an interview, and from otolaryngologist information regarding the injury location (central, peripheral, or mixed) and extent (mild, moderate, or severe).$^{10}$ It is composed of static and dynamic equilibrium and cerebral tests; nystagmus position and positioning; and vectoelectronystagmography (VENG). ${ }^{11}$ The last test captured the vestibular-ocular reflex from correctly positioned electrodes, allowing the recording and analysis of the characteristics of the functional behavior of the reflex. ${ }^{12}$ This test is performed with caloric tests, which, despite using non-physiological stimulus, is the most important test among the several used in VT. Through this test, thermal variations are created within the external auditory canal that propagate through the middle and inner ear and, thus, affect the lateral semicircular canal (LSCC). This stimulation produces an endolymphatic current whose direction depends on the temperature of the stimulus used (hot or cold). When the stimulation is hot, an ampullopetal current is generated. When the stimulation is cold, an ampullofugal current is generated. The action of these currents on the ampullary crest alters the action potential, stimulating or inhibiting and thus generating nystagmus. Based on the results of this test, one can determine the side of the injury or if there is a predominance of nystagmus in a certain direction. ${ }^{13}$ Thus, the nystagmus responses found in four stimulations allow us to interpret the evidence in caloric nystagmus directional preponderance (DP) or unilateral weakness (UW) according to the Jongkees formula. ${ }^{14}$ UW occurs when the observed responses in one ear are smaller than the responses obtained in the other ear, indicating a unilateral vestibular function deficit. ${ }^{15} \mathrm{DP}$ is characterized by larger responses found in the same direction as the nystagmus, and clinically, this asymmetry in the vestibular-ocular reflex can be caused by injuries in the labyrinth, vestibular nerve, vestibular nuclei, or central injuries. ${ }^{15,16}$

In the literature, there are differences in relation to the standards for normal caloric tests, especially as the reference values for UW and DP may vary between different authors. $^{13,15}$ In Brazil, UW or DP percentage values above 33\% are indicative of vestibular dysfunction, ${ }^{11,17,18}$ whereas internationally, authors tend to adopt considerably smaller UW and DP percentage values, ${ }^{13-16,18-21}$ as shown in - Table 1. Such variations have a direct impact on the results of vestibular testing.

Although the caloric test is an important tool in vestibular evaluations, ${ }^{13}$ it is not able to identify the influence of dizziness on the quality of life of individuals with balance disorders. In 1990, researchers developed a questionnaire specific for this purpose, the Dizziness Handicap Inventory (DHI). ${ }^{22}$ This questionnaire aims to investigate the self-perception of dizziness, and its impact on the quality of life of individuals, containing 25 questions related to emotional, physical, and functional factors. In 2003, the questionnaire was translated and adapted to Portuguese (DHI Brasileiro [Brazilian DHI]). ${ }^{23}$

Studies report the importance of the application of the DHI to quantify the limiting effects, to provide treatment guidance, for its contribution to the diagnosis of vestibular disease, and to verify the effectiveness of vestibular rehabilitation. 23,24

This study aims to evaluate the impact of dizziness on the quality of life of individuals undergoing vestibular testing and to compare, analyze, and correlate the results obtained for UW and DP in accordance with Brazilian and international criteria.

Table 1 Patterns of normality found for UW and DP (water irrigation) according to several authors

\begin{tabular}{|c|c|c|c|}
\hline \multicolumn{2}{|l|}{ Author (year) } & \multicolumn{2}{|c|}{ Normality values } \\
\hline & & \multirow{2}{*}{$\begin{array}{l}\text { UW } \\
33 \%\end{array}$} & \multirow{2}{*}{$\begin{array}{l}\text { DP } \\
33 \%\end{array}$} \\
\hline National & Caovilla et al. ${ }^{10}$ & & \\
\hline & Gama, Soares $^{11}$ & $33 \%$ & $33 \%$ \\
\hline & Mor et al. ${ }^{17}$ & $33 \%$ & $33 \%$ \\
\hline \multirow[t]{8}{*}{ International } & Jongkees $^{14}$ & $20 \%$ & $22 \%$ \\
\hline & Sills et al. ${ }^{16}$ & $25 \%$ & $23 \%$ \\
\hline & Jacobson et al. ${ }^{18}$ & $20 \%$ & $27 \%$ \\
\hline & Henry $^{19}$ & $25 \%$ & $30 \%$ \\
\hline & Van der Stappen et al. ${ }^{20}$ & $22 \%$ & $19 \%$ \\
\hline & Fife et al. $^{13}$ & $22-25 \%$ & $26-30 \%$ \\
\hline & Baloh, Honrubia ${ }^{21}$ & $25 \%$ & $30 \%$ \\
\hline & Barin $^{15}$ & $25 \%$ & $23 \%$ \\
\hline
\end{tabular}




\section{Method}

This work is a cross-sectional observational study approved by the Ethics Committee of the institution under number 0551/11.

The non-probabilistic sample consisted of 235 patients older than 18 years treated in audiology services from two hospitals. All patients complained of dizziness, and were referred by otolaryngologists from the various health centers of the city to undergo VT.

To properly administer the exam, the patients were instructed to take no medications for dizziness or consume no alcoholic beverages for 72 hours; furthermore, the patients underwent a three-hour fast before the exam.

During their stay in the waiting room, each patient was invited to participate, and, upon agreeing, all participants signed an informed consent form. Subsequently, trained interviewers were responsible for applying the Brazilian DHI.

Next, each individual underwent an interview, and subsequently completed assessment tests on static and dynamic equilibrium (Romberg tests, Romberg-Barré, and Unterberger), and cerebellar function (Naso-Index and Diadococinesia tests). Then, a study of the positional nystagmus and positioning was performed. Researchers cleaned each patient's skin with alcohol, and positioned electrodes with electrolytic gel, attaching them with adhesive tape. A triangular layout of the electrodes was used for VENG. ${ }^{25}$ The authors evaluated individuals' saccadic movements, spontaneous nystagmus with their eyes open, and closed, semispontaneous nystagmus, pendular screening, and optokinetic nystagmus. ${ }^{15,26,27}$

To perform the caloric test, the head of the stretcher was elevated to $30^{\circ}$, and a Berger ${ }^{\circledR}$ brand (Eletromedicina, Säo Paulo, SP, Brazil) otocalorimeter with a flow of $200 \mathrm{ml}$ of water was used for 40 seconds. ${ }^{15}$ Before irrigation, all patients underwent an otoscopy to ensure absence of foreign bodies or cerumen in their external ear. Irrigation was performed with water at temperatures of $44^{\circ}$ and $30^{\circ} \mathrm{C}$, in the following sequence: $44^{\circ}$ in the right ear, $44^{\circ}$ in the left ear, $30^{\circ}$ in the left ear, and $30^{\circ}$ in the right ear.

During the caloric test, the subjects kept their eyes closed during irrigation, having been advised of the possibility of experiencing dizziness or nausea. All measures were taken to minimize these symptoms, such as spontaneous conversation, and eye fixation to inhibit the nystagmus.
After analyzing the results, the participants were divided into three groups according to the UW and DP values obtained. Group 1 consisted of individuals who presented results of less than $20 \%$ UW and/or less than $27 \%$ DP (normal according to international standards). Group 2 included all patients whose UW was between 20 and 33\% and/or whose DP was between 27 and 33\%. Group 3 included all individuals with UW and DP above 33\% (modified according to Brazilian criteria).

The data were entered into a spreadsheet in SPSS version 17.0 , and all individuals were regrouped to satisfy the criteria for national and international analyses.

Frequencies were compared between groups in relation to the variables analyzed using the chi-square test. Differences with levels of less than or equal to $5 \%$ significance were considered significant.

\section{Result}

Of the 235 participants, 49 (20.9\%) were male and $186(79.1 \%)$ were female. The average age was 54.8 years $( \pm 15.31)$, ranging from 18 to 93 years. The largest group consisted of individuals aged between 41 and 60 years (42.1\%), followed by the group of individuals aged over 61 years (41.3\%). - Tables 2 and 3 present data on the age and gender of the participants, respectively.

Regarding the Brazilian DHI, the averages for the total score and the three subscales (physical, functional, and emotional) were approximate in the three groups, as shown in - Table 4. Statistical analysis using ANOVA revealed no significant difference for total score or any subscale of the Brazilian DHI in any group.

To evaluate the test results, individuals were redistributed according to the values obtained for UW and DP, according to the national and international standards. Thus, according to national criteria, tests were considered normal when UW and DP were up to 33\%; tests were considered modified when UW and DP were above this value. According to international criteria, tests were considered normal when UW was below $20 \%$ and DP was below 27\%; tests were considered modified when the results were above these values. - Table 5 compares the results of UW and DP obtained for each criterion. Statistical analysis using the chi-square test revealed a statistically significant difference between the results found in both criteria $(p=0.000)$.

Table 2 Descriptive gender data for participant groups

\begin{tabular}{|l|l|l|l|l|l|}
\hline Gender & $\begin{array}{l}\text { Group 1 } \\
\text { N (\%) }\end{array}$ & $\begin{array}{l}\text { Group 2 } \\
\text { N (\%) }\end{array}$ & $\begin{array}{l}\text { Group 3 } \\
\text { N (\%) }\end{array}$ & $\begin{array}{l}\text { Total } \\
\text { N (\%) }\end{array}$ & -value \\
\hline Male & $29(12.3)$ & $14(5.9)$ & $6(2.6)$ & $49(20.8)$ & $0.039^{*}$ \\
\hline Female & $94(40.0)$ & $38(16.2)$ & $54(23.0)$ & $186(79.2)$ \\
\hline Total & $123(52.3)$ & $52(22.1)$ & $60(25.6)$ & $235(100.0)$ & \\
\hline
\end{tabular}

Group 1: normal UW and DP according to international criteria; Group 2: UW with values between 20 and $33 \%$ and DP between 27 and $33 \%$; Group 3: UW and DP according to national criteria. * $\mathrm{p}$ : $\mathrm{p}$-value observed in the chi-square test.

Abbreviation: DP, directional preponderance; N, number of individuals; UW, unilateral weakness. 
Table 3 Age distribution within each group

\begin{tabular}{|c|c|c|c|c|}
\hline \multirow[t]{2}{*}{ Age } & Group 1 & Group 2 & Group 3 & Total \\
\hline & $(N=123)$ & $(N=52)$ & $(N=60)$ & $(N=235)$ \\
\hline Minimum & 18 & 18 & 19 & 18 \\
\hline Maximum & 91 & 93 & 84 & 93 \\
\hline Median & 59.00 & 54.50 & 56.50 & 57.00 \\
\hline Mean & 56.67 & 53.25 & 55.20 & 55.53 \\
\hline SD & 14.61 & 16.32 & 14.51 & 14.98 \\
\hline p-value & \multicolumn{4}{|c|}{0.36} \\
\hline
\end{tabular}

Group 1: normal UW and DP according to international criteria; Group 2: UW with values between 20 and 33\% and DP between 27 and 33\%; Group 3: UW and DP according to national criteria. p-value: value of $\mathrm{p}$ observed in the chi-square test.

Abbreviation: DP, directional preponderance; N, number of individuals; UW, unilateral weakness.

Table 4 Descriptive statistics and comparisons between age groups and Brazilian DHI subscales

\begin{tabular}{|c|c|c|c|c|c|c|c|c|c|}
\hline \multirow{2}{*}{\multicolumn{2}{|c|}{ Variables }} & \multirow[t]{2}{*}{ Values } & \multirow{2}{*}{$\begin{array}{l}\text { Group } 1 \\
\text { UW \& DP } \\
(N=120)\end{array}$} & \multicolumn{3}{|l|}{ Group 2} & \multicolumn{3}{|l|}{ Group 3} \\
\hline & & & & $\begin{array}{l}\text { UW } \\
(N=37)\end{array}$ & $\begin{array}{l}\text { DP } \\
(N=11)\end{array}$ & $\begin{array}{l}\text { UW\&DP } \\
(N=6)\end{array}$ & $\begin{array}{l}\text { UW } \\
(N=26)\end{array}$ & $\begin{array}{l}\mathrm{DP} \\
(N=30)\end{array}$ & $\begin{array}{l}\text { UW\&DP } \\
(N=5)\end{array}$ \\
\hline \multirow{5}{*}{\multicolumn{2}{|c|}{ Age }} & Minimum & 18 & 18 & 18 & 51 & 19 & 29 & 21 \\
\hline & & Maximum & 91 & 75 & 78 & 93 & 81 & 84 & 72 \\
\hline & & Mean & 56.88 & 53.00 & 49.55 & 60.83 & 52.65 & 58.00 & 52.00 \\
\hline & & SD & 14.68 & 14.21 & 21.22 & 16.80 & 15.52 & 12.39 & 19.43 \\
\hline & & p-value & \multicolumn{7}{|c|}{0.36} \\
\hline \multirow[t]{20}{*}{ Brazilian DHI } & \multirow[t]{5}{*}{$\mathrm{PH}$} & Minimum & 0 & 0 & 0 & 0 & 4 & 2 & 14 \\
\hline & & Maximum & 28 & 28 & 26 & 24 & 28 & 28 & 22 \\
\hline & & Mean & 15.27 & 14.38 & 16.55 & 15.67 & 15.77 & 16.27 & 16.80 \\
\hline & & SD & 7.71 & 7.84 & 7.65 & 10.69 & 6.70 & 8.01 & 3.90 \\
\hline & & p-value & \multicolumn{7}{|c|}{0.96} \\
\hline & \multirow[t]{5}{*}{ FU } & Minimum & 0 & 0 & 2 & 0 & 4 & 0 & 6 \\
\hline & & Maximum & 36 & 36 & 32 & 30 & 32 & 36 & 32 \\
\hline & & Mean & 17.17 & 20.05 & 18.91 & 19.33 & 17.77 & 17.87 & 20.80 \\
\hline & & SD & 10.51 & 11.39 & 9.48 & 11.64 & 7.45 & 9.37 & 10.64 \\
\hline & & p-value & \multicolumn{7}{|c|}{0.82} \\
\hline & \multirow[t]{5}{*}{ EM } & Minimum & 0 & 0 & 0 & 0 & 0 & 0 & 2 \\
\hline & & Maximum & 34 & 36 & 30 & 30 & 36 & 36 & 22 \\
\hline & & Mean & 13.53 & 14.65 & 12.18 & 17.67 & 15.08 & 12.53 & 8.80 \\
\hline & & SD & 9.63 & 11.02 & 9.40 & 11.06 & 10.08 & 10.46 & 7.82 \\
\hline & & p-value & \multicolumn{7}{|c|}{0.72} \\
\hline & \multirow[t]{5}{*}{ Total } & Minimum & 0 & 0 & 4 & 4 & 14 & 6 & 24 \\
\hline & & Maximum & 96 & 100 & 86 & 86 & 92 & 96 & 74 \\
\hline & & Mean & 45.95 & 49.35 & 47.64 & 53.00 & 48.62 & 46.67 & 46.40 \\
\hline & & SD & 24.68 & 28.74 & 24.51 & 31.67 & 20.53 & 24.37 & 20.46 \\
\hline & & p-value & \multicolumn{7}{|c|}{0.99} \\
\hline
\end{tabular}

Abbreviations: EM, emotional; FU, functional; N, absolute minimum; PH, physical; p-value, p value using ANOVA; SD, standard deviation. 
Table 5 UW and DP results obtained according to national and international criteria

\begin{tabular}{|l|l|l|l|l|}
\hline \multicolumn{2}{|l|}{ UW and DP (criteria) } & $\begin{array}{l}\text { Normal } \\
\text { N (\%) }\end{array}$ & $\begin{array}{l}\text { Altered } \\
\text { N (\%) }\end{array}$ & $\begin{array}{l}\text { Total } \\
\text { N (\%) }\end{array}$ \\
\hline \multirow{2}{*}{ UW } & National & $204(86.8 \%)$ & $31(13.2 \%)$ & $235(100 \%)$ \\
\cline { 2 - 5 } & International & $154(65.5 \%)$ & $81(34.5 \%)$ & $235(100 \%)$ \\
\hline \multirow{2}{*}{ DP } & National & $200(85.1 \%)$ & $35(14.9 \%)$ & $235(100 \%)$ \\
\cline { 2 - 5 } & International & $180(76.6 \%)$ & $55(23.4 \%)$ & $235(100 \%)$ \\
\hline
\end{tabular}

Abbreviations: \%, percentage; DP, directional preponderance; N, absolute number; UW, unilateral weakness.

\section{Discussion}

Regarding gender, $79.1 \%$ of the individuals were women, and $20.9 \%$ were men, corroborating other studies in the literature that refer to females as having the most complaints of dizziness. ${ }^{25,28-31}$ This fact can be explained by the age of the sample, as several studies have reported that women over 45 are more prone to dizziness due to hormonal disorders related to menopause. ${ }^{32,33}$

The average age was 54.8 years $( \pm 15.31)$, and the most numerous group consisted of individuals aged between 41 and 60 years (42.1\%), followed by the group of individuals aged over 61 years (41.3\%). A total of $83.4 \%$ of the sample consisted of individuals aged over 40 years, and only $16.6 \%$ of participants were younger than 40 years. The same results were found in other studies, showing that the presence of dizziness is directly related to increased age. ${ }^{25,34}$ Several factors explain the greater incidence of dizziness in this population, for example, anxiety; depressive symptoms; hearing loss; aging of the inner ear, the cochlea, and the labyrinth; using five or more medications; presence of postural hypotension; and postural equilibrium disorders. $^{7,29,31}$

The impact of dizziness on the quality of life of an individual has been increasingly studied. ${ }^{26}$ Several studies have used the Brazilian DHI as a suitable tool to assess the limiting effects of dizziness; furthermore, this tool is easy to use, and easy for the patients to understand. ${ }^{28,35}$ In this study, results showed subjects with normal and high examination scores on the DHI, demonstrating that, for some patients with normal test results, dizziness has a higher impact on the patient's quality of life. However, there were individuals with modified results in the national criterion (UW and/or DP greater than 33\%) with low scores on the Brazilian DHI. Statistical analysis comparing the results found in all DHI subscales for the three groups showed no relationship between abnormal test results and scores. This finding can be explained by the fact that the symptoms that accompany dizziness are directly impacted by the lifestyle, motivations, and psychological state of the individual. ${ }^{36}$ Thus, it is possible that two or more people have the same otoneurologic diagnosis, yet their daily activities are affected differently by dizziness. Therefore, this study highlights the need to evaluate not only vestibular testing results but also how an individual perceives dizziness and how dizziness interferes in activities of daily living.
It is known that normality criterion has a direct impact on clinical care. If more individuals exhibit alterations in a test, the care demands will be greater to solve these cases. Additionally, there is a need to expand the number of trained professionals in the area as well as to improve the outpatient physical structure of the health network. ${ }^{37,38}$

In fact, the parameter used impacts not only clinical care but also the entire health system, which should prioritize a patient's comprehensive care through an individual-based model. ${ }^{39}$ Accordingly, the percentage increase in vestibular tests considered abnormal may contribute to better monitoring and treatment of patients with vestibular disorders that manifest symptoms that interfere with their quality of life, ${ }^{28}$ which is often neglected in the health care process. In addition, vestibular rehabilitation may be a recommended alternative for patients. This procedure can be performed by primary health care professionals for the Núcleos de Apoio em Saúde da Família [Centers of Family Health Support]. ${ }^{39}$ Several studies show the effectiveness of vestibular rehabilitation and its effect on the quality of life of patients, ${ }^{40-42}$ who suffer losses arising from the presence of dizziness, regardless of possible syndromic and associated topographical diagnoses. $^{43,44}$

Although the parameters for the analysis of UW and DP are reported in the literature for the same type of irrigation (closed circuit water), one should consider that there are variables that can affect the results of several studies. These differences occur not only due to individual variability in the caloric test itself, but also due to differences in equipment, irrigation parameters, or statistical analysis methods. However, as shown in - Table $\mathbf{5}$, there is a difference between the values adopted internationally and the values adopted in Brazil, especially in relation to UW. Therefore, this study points to the need for an internal review to establish standard values for UW and DP in different national audiology services. This would ensure that the standards adopted are consistent with the international scientific reality and that the results produced effectively incorporate the complaints filed by individuals experiencing dizziness who undergo vestibular testing.

No studies were found in the literature comparing the impact of dizziness on the quality of life of patients undergoing vestibular testing in Brazil and internationally. However, dizziness can generate various losses in the quality of life of individuals. Therefore, it is believed that a review of the normal values for UW and DP adopted in Brazil is required. 
It is suggested that the Brazilian DHI be applied to all patients undergoing VT as an additional tool to assess the impact of dizziness on quality of life. In this sense, if a patient has normal VT but the values found in the Brazilian DHI are high, it is important to consider the possibility of the doctor referring the patient for appropriate treatment to minimize the impact of dizziness on quality of life.

\section{Conclusion}

The results of this study showed no relationship between the impact of dizziness in the quality of life of patients and the results of vestibular tests. Both the national and international criteria used to analyze the UW and DP results had a direct influence on the outcome of the VT and, consequently, on the clinical decision regarding a therapeutic approach for the patient.

\section{References}

1 Flores FT, Rossi AG, Schmidt PS. Avaliação do equilíbrio corporal na doença de Parkinson. Int Arch Otorhinolaryngol 2011;15(2): 142-150

2 Santos JLP. Elaboração de uma plataforma oscilatória para teste de equilíbrio dinâmico [dissertation]. Guaratinguetá: Universidade Estadual Paulista; 2011:27

3 Paulino CA, Prezotto PO, Calixto RF. Associação entre estresse, depressão e tontura: uma breve revisão. Rev Equilíbrio Corporal e Saúde 2009;1:33-45

4 Rocha Júnior PR, Kozan ES, Moraes JF, Pereira FG, Moreno AB. Vestibular rehabilitation in the quality of life and the symptomatology of dizziness among the elderly. Cien Saude Colet 2014; 19(8):3365-3374

5 Batista JS, Pasqualotti A, Marchi ACB, Wibelinger LM. Exercícios de reabilitação vestibular em idosos. Revista Contexto \& Saúde 2011; 10(20):969-974

6 Silva TL, Martinez EZ, Manço ARX, Junior APS, Arruda MF. A associação entreo a ocorrência de quedas e a alteração de equilíbrio e marcha em idosos. Rev Saúde e Pesquisa 2014;7(1):25-34

7 Scherer S, Lisboa HRK, Pasqualotti A. Tontura em idosos: diagnóstico otoneurológico e interferência na qualidade de vida. Rev Soc Bras Fonoaudiol 2012;17(2):142-150

8 Santana GG, Doná F, Ganança MM, Kasse CA. Vestibulopatia no Idoso. Saúde Coletiva 2011;48(8):52-56

9 Lourenço EA, Lopes KD, Jr AP, Oliveira MH, Umemura A, Vargas AL. Distribuição dos achados otoneurológicos em pacientes com disfunção vestíbulo-coclear. Rev Bras Otorrinolaringol 2005;71(3):34-38

10 Caovilla HH, Ganança MM, Munhoz MSL, Silva MLG. Equilibriometria Clínica. São Paulo: Atheneu; 1999:1-3

11 Gama MR, Soares E. Resolvendo casos em audiologia. São Paulo: Ed. Plexus; 2001:112-5

12 Ganança MM, Mangabeira Albernaz PL. I. Semiologia vestibular. 8. Eletro-oculografia. In: Labirintologia: guia prático. São Paulo: Editamed; 1976:17-21

13 Fife TD, Tusa RJ, Furman JM, et al. Assessment: vestibular testing techniques in adults and children: report of the Therapeutics and Technology Assessment Subcommittee of the American Academy of Neurology. Neurology 2000;55(10):1431-1441

14 Jongkees LBW, Philipszoon AJ. Eletronystagmography. Acta Otolaryngol Suppl 1964;189:189

15 Barin K. Background and technique of caloric testing. In: Jacobson GP, Shepard NT. Balance Function Assessment and Management. San Diego: Plural Publishing; 2008:197-228
16 Sills AW, Baloh RW, Honrubia V. Caloric testing 2: results in normal subjects. Ann Otol Rhinol Laryngol Suppl 1977;86(5 Pt 3, Suppl 43):7-23

17 Mor R, Fragoso M, Taguchi CK, Figueiredo JFFR. Vestibulometria e Fonoaudiologia: como realizar a interpretar. São Paulo: Ed. Lovise; 2001:98-107

18 Jacobson GP, Newman CW, Peterson EL. Interpretation and usefulness of caloric testing. In: Jacobson GP, Newman CW, Kartush JM, eds. Handbook of balance testing function. St Louis: Mosby1993: 193-223

19 Henry DF. Test-retest reliability of open-loop bithermal caloric irrigation responses from healthy young adults. Am J Otol 1999; 20(2):220-222

20 Van Der Stappen A, Wuyts FL, Van De Heyning PH. Computerized electronystagmography: normative data revisited. Acta Otolaryngol 2000;120(6):724-730

21 Baloh RW, Honrubia V. Clinical neurophysiology of the vestibular system. $3^{\text {rd }}$ ed. New York: Oxford University Press; 2001:136-46

22 Jacobson GP, Newman CW. The development of the Dizziness Handicap Inventory. Arch Otolaryngol Head Neck Surg 1990; 116(4):424-427

23 Castro ASO, Gazzola JM, Natour J, Ganança FF. Brazilian version of the dizziness handicap inventory. Pro Fono 2007;19(1):97-104

24 Moreira DA, Bohlsen YA, Momensohn-santos TM, Cherubini AA. Study of the Handicap Caused by Dizziness in Patients Associated or Not with Tinnitus Complaint. Int Arch Otorhinolaryngol 2006; 10(4):270-277

25 Ganança MM, Caovilla HH, Ganança FF. Electronystagmography versus videonystagmography. Braz J Otorhinolaryngol 2010; 76(3):399-403

26 Furman JM, Cass SP. Vestibular disorders: a case study approach. 2nd ed. New York: Oxford University Press; 2003:30-41

27 SBFa. Guia prático de procedimentos fonoaudiológicos na avaliação vestibular. São Paulo: Sociedade Brasileira de Fonoaudiologia; 2011:11-21

28 Takano NA, Cavalli SS, Ganança MM, et al. Quality of life in elderly with dizziness. Braz J Otorhinolaryngol 2010;76(6):769-775

29 Bento RF, Bohadana SC, Lima S, Silveira JA. Sintomas vestibulares e alterações no exame eletronistagmográfico: estudo de 230 casos. Braz J Otorhinolaryngol 1998;64(4):397-403

30 Gurgel LG, Dourado MR, Moreira TC, et al. Correlation between vestibular test results and selfreported psychological complaints of patients with vestibular symptoms. Braz J Otorhinolaryngol 2012;78(1):62-67

31 Silva BSR, Sousa GB, Russo ICP, Silva JAPR. Caracterização das queixas, tipo de perda auditiva e tratamento de indivíduos idosos atendidos em uma clínica particular de Belém - PA. Int Arch Otorhinolaryngol 2007;11(4):387-395

32 Barrett-Connor E, Weiss TW, McHorney CA, Miller PD, Siris ES. Predictors of falls among postmenopausal women: results from the National Osteoporosis Risk Assessment (NORA). Osteoporos Int 2009;20(5):715-722

33 Halil M, Ulger Z, Cankurtaran M, et al. Falls and the elderly: is there any difference in the developing world? A cross-sectional study from Turkey. Arch Gerontol Geriatr 2006;43(3):351-359

34 Felipe L, Simões LC, Gonçalves DU, Mancini PC. Evaluation of the caffeine effect in the vestibular test. Braz J Otorhinolaryngol 2005; 71(6):758-762

35 Handa PR, Kuhn AMB, Cunha F, Schaffleln R, Ganança FF. Qualidade de vida em pacientes com vertigem posicional paroxística benigna e/ou doença de Meniere. Braz J Otorhinolaryngol 2005;71(6): 776-783

36 Paiva AD, Kuhn AMB. Sintomas psicológicos concomitantes à queixa de vertigem em 846 prontuários de pacientes otoneurológicos do Ambulatório de Otoneurologia da Universidade Federal de São Paulo -Escola Paulista de Medicina. Braz J Otorhinolaryngol 2004;70(4):512-515 
60 The Impact of Dizziness on the QoL of Individuals after Vestibular Test in Brazil Burle et al.

37 Santos JN, Maciel FJ, Martins VO, Rodrigues ALV, Gonzaga AF, Silva LF. Inserção dos fonoaudiólogos no SUS/MG e sua distribuição no território do Estado de Minas Gerais. Rev CEFAC 2012;14(2):196-205

38 Volpato LF, Meneghim MdeC, Pereira AC, Ambrosano GMB. Quality planning of Family Health Units using Quality Function Deployment (QFD). Cad Saude Publica 2010;26(8):1561-1572

39 Ribeiro MMF, Amaral CFS. Patient-centered care and medical teaching: the importance of caring and sharing. Rev Bras Educ Med 2008;32(1):90-97

40 Mantello EB, Moriguti JC, Junior ALR, Ferrioli E. Vestibular rehabilitation's effect over the quality of life of geriatric patients with labyrinth disease. Braz J Otorhinolaryngol 2008;74(2):172-180
41 Pereira AB, Santos JN, Volpe FM. Effect of Epley's maneuver on the quality of life of paroxismal positional benign vertigo patients. Braz J Otorhinolaryngol 2010;76(6):704-708

42 Peres M, da Silveira E. Effect of vestibular rehabilitation in elder people: regarding balance, quality of life and perception. Cien Saude Colet 2010;15(6):2805-2814

43 Ganança FF, Castro ASO, Branco FC, Natour J. Interferência da tontura na qualidade de vida de pacientes com síndrome vestibular periférica. Braz J Otorhinolaryngol 2004;70(1):94-101

44 Santos EM, Gazzola JM, Ganança CF, Caovilla HH, Ganança FF. Impact of dizziness on the life quality of elderly with chronic vestibulopathy. Pro Fono 2010;22(4):427-432 